\title{
IMPLEMENTASI PENDIDIKAN SEKS BERBASIS SEKOLAH
}

\author{
Siti Maimunah \\ Fakultas Psikologi Universitas Muhammadiyah malang \\ sitimaimunah20@gmail.com
}

\begin{abstract}
Abstrak. Penelitian ini bertujuan untuk menerapkan model pendidikan seks di sekolah. Subjek yang terlibat dalam penelitian ini terdiri dari 6 guru dan 60 siswa yang telah dipilih berdasarkan kriteria khusus yang telah ditetapkan dan mereka bersedia mengikuti program dari awal hingga selesai. Desain penelitian yang digunakan dalam penelitian ini adalah one group pretest posttest design. Hasil penelitian menunjukkan bahwa program ini mampu meningkatkan pengetahuan dan keterampilan guru-guru dalam mengajarkan materi pendidikan seks. Hal ini ditunjukkan dengan nilai mean sebelum dilakukan intervensi adalah 4, 17 dan setelah pelaksanaan adalah 22,33 dan nilai r sebesar -0,878 dan nilai t sebesar -27,776. Pada siswa, program ini juga terbukti efektif dalam meningkatkan pengetahuan siswa, merubah sikap terhadap seks pranikah dan mengurangi intensi untuk terlibat dalam perilaku seks pranikah
\end{abstract}

\section{Kata Kunci : Pengetahuan, Pendidikan Seks, Remaja}

Abstract. This study aims to apply the model of sex education in schools. The subjects involved in this study consisted of 6 teachers and 60 students who had been selected based on specific criteria set and they were willing to take the program from start to finish. The research design used in this study is one group pretest posttest design. The results showed that this program was able to improve the knowledge and skills of teachers in teaching sex education material. This is indicated by the mean value before intervention is 4, 17 and after implementation is 22.33 and the $r$ value is -0.887 and the $t$ value is -27.776. For students, this program has also proven effective in increasing student knowledge, changing attitudes towards premarital sex and reducing the intention to engage in premarital sexual behavior.

Keywords: Adolescent, Knowledge, Sex education

Banyak guru yang belum memahami tentang pendidikan seks, maka tentu saja mereka belum mengetahui bagaimana model pendidikan seks yang sesuai untuk siswanya di sekolah. Selain itu, tidak semua sekolah memiliki kebijakan untuk mengajarkan pendidikan seks di sekolah dengan berbagai alasan.

Dewasa ini, siswa berusia remaja dihadapkan pada permasalahan atau isu-isu kesehatan fisik dan kesehatan mental antara lain kehamilan yang tidak diinginkan, depresi, asma, obesitas, anorexia, bunuh diri dan bullying. Hal ini tentu saja akan berpengaruh terhadap nilai akademis mereka. Beberapa hasil riset menunujukkan secara konsisten bahwa status kesehatan dan prestasi belajar siswa berpengaruh secara langsung, kesehatan siswa baik secara fisik maupun mental merupakan salah satu faktor yang berpengaruh secara signifikan terhadap pembelajaran dan prestasi siswa (Pryor, 2012).

Banyak remaja yang terlibat dalam perilaku berisiko yaitu perilaku yang berdampak pada keberhasilan proses pendidikan, menimbulkan masalah baik secara fisik, kesehatan, perilaku dan sosial. Perilaku berisiko yang banyak dilakukan oleh remaja diantaranya 
yaitu minum minuman keras atau beralkohol, penggunaan obat-obatan terlarang, tindakan kriminal, berkendara secara liar, seks pranikah dan lain-lain. Data penelitian tentang perilaku berisiko yang dilakukan oleh remaja seperti yang dilansir oleh Gruber (2001) yaitu setengah dari siswa sekolah menengah di Michigan telah melakukan hubungan intim dan 10 persennya mengalami kehamilan, $80 \%$ siswa terlibat dalam minuman beralkohol dan $63 \%$ diantara mereka mabuk berat, $10 \%$ melakukan percobaan bunuh diri, dan $20 \%$ terlibat penggunaan penyalahgunaan obat terlarang.

Sementara Ahmed, Abu-Ras \& Arfken (2014) menunjukkan bahwa prevalensi perilaku berisiko yang dilakukan siswa menunjukkan 53.8\% siswa telah melakukan hubungan seks pra-nikah, 46.2\% pernah menggunakan alkohol, $37.3 \%$ merokok dan $24.6 \%$ menggunakan obat-obatan terlarang. Ada $77.6 \%$ siswa yang terlibat dua atau lebih perilaku berisiko.

Perilaku berisiko ini tentu saja akan menghambat dan berdampak negatif bagi keberhasilan mereka di dunia pendidikan khususnya ( Terzian, Andrews \& Moore, 2011). Mereka akan terancam gagal atau lulus tidak tepat waktu. Oleh karena itu sangat penting diadakan program khusus pendidikan kesehatan di sekolah, dan pendidikan kesehatan seks merupakan salah satu tema yang bisa diagendakan dalam proses pendidikan kesehatan di sekolah. Hal ini karena dari beberapa perilaku berisiko yang cenderung dilakukan oleh remaja menunjukkan bahwa seks pranikah menduduki tempat yang tertinggi dari beberapa perilaku berisiko lainnya.

Pendidikan seksual merupakan program pendidikan yang melibatkan kombinasi pengalaman yang memungkinkan peserta didik untuk; mendapatkan pengetahuan yang berkaitan dengan masalah kesehatan secara spesifik, mengembangkan motivasi dan wawasan pribadi yang penting bagi tindakan yang dilakukan atas pengetahuan yang dimiliki, mendapatkan keterampilan yang mungkin perlu mereka pertahankan dan kembangkan terkait kesehatan seksual dan menghindari masalah seksual, serta membantu menciptakan lingkungan yang kondusif bagi kesehatan seksual (McCall, 2004)

Fase remaja merupakan masa perkembangan individu yang sangat penting karena masa ini merupakan masa yang amat kritis yang mungkin dapat merupakan the best of time and the worst of time bagi individu yang bersangkutan (Simon, Chao, Conger, \& Elder, 2001). Mengingat pentingnya fase ini, sudah selayaknya kita memberikan dukungan yang positif dalam perkembangan mereka, salah satunya adalah membekalinya dengan pemahaman kesehatan seksual sehingga terhindar dari perilaku berisiko.

Perkembangan fisik remaja akan mengalami kematangan organ-organ seks dan kemampuan reproduktif yag bertumbuh dengan cepat. Kondisi ini disebut dengan kematangan seksual. Kematangan seksual ini memberikan efek pada remaja yaitu mengakibatkan mereka mulai tertarik terhadap anatomi fisiologi tubuhnya, mulai muncul kecemasan-kecemasan dan pertanyaan-pertanyaan seputar menstruasi, mimpi basah, masturbasi, ukuran buah dada, penis dan lain sebagainya (Smida, Hadhri, Bolje, Cafsi, \& Bedoui, 2014).

Pertumbuhan fisik remaja yang telah mencapai bentuk yang sempurna cenderung mengundang masalah bagi orang dewasa di sekitarnya atau bagi teman sebayanya. Mereka rawan menjadi korban penyalahgunaan seks atau bahkan bisa jadi mereka juga akan menjadi pelaku. Banyak faktor yang membuat mereka akan mengalami kondisi 
demikian antara lain adalah karena faktor media, lingkungan dan dukungan yang diterima.

Dukungan eksistensi remaja dari lingkungan terdekat baik itu orangtua maupun guru sangat dibutuhkan pada tahapan ini, hal ini karena pada fase ini remaja akan mengalami kebingungan dengan perubahan kondisi fisiknya dan keingintahuan yang tinggi terkait perubahan fisiknya tak terkecuali terkait dengan seksualitas. Realita yang terjadi baik guru maupun orangtua kurang atau bahkan tidak pernah memberikan informasi yang dibutuhkan oleh remaja. Kondisi ini menyebabkan remaja lebih memilih teman sebaya untuk berkeluh kesah dan bercerita semua yang mereka alami dan yang mereka ingin ketahui, dan salah satunya adalah terkait dengan perkembangan seksualitas mereka. Hal ini juga merupakan cara bagi remaja untuk membandingkan dirinya dengan teman sebayanya terkait perkembangan fisik yang mereka alami (Kretsch, Mendle, Cance, Harden, 2015).

Menurut Jaccard, Blanton dan Dodge (2005) bahwa teman sebaya merupakan salah satu faktor yang berkontribusi dalam mempengaruhi perilaku seks pada remaja. Penelitian lain juga menunjukkan hal yang sama yaitu ada pengaruh yang signifikan antara teman sebaya terhadap perilaku seks remaja (Pramono, Dewi dan Auliatunida, 2011).

Belum lagi media eletronik yang canggih dan sangat memudahkan remaja dalam mencari informasi yang mereka inginkan khususnya terkait seksual. Hal ini seperti hasil penelitian yang dilakukan oleh Chaves, Tortolero, Markham, Low, Eitel dan Thickstun (2005) yang menyatakan bahwa media memberikan kontribusi dalam perilaku remaja seperti kekerasan, gangguan makan, penggunaan alkohol dan obat-obatan serta perilaku seksual.

Oleh karena itu, penting membuat program terkait pendidikan kesehatan khususnya pendidikan seksual. Peneliti dari Dhaka yaitu Islam dan Rahman (2008) menyatakan bahwa pendidikan seks adalah adalah istilah luas yang digunakan untuk menggambarkan pendidikan tentang anatomi seksual manusia, reproduksi seksual, hubungan seksual, dan aspek lain dari perilaku seksual manusia. Pendidikan seks adalah tentang mengetahui anatomi dan fisiologi tubuh manusia, atau tentang tindakan seks dan kehidupan keluarga, atau tentang pencegahan penyakit menular seksual dan kehamilan yang tidak diinginkan. Ini juga berarti tentang bagaimana mengetahui etika sosial, moral dan agama, bagaimana menghindari tekanan teman sebaya, pertumbuhan dan perkembangan seksual, waktu pubertas, perubahan fisik selama pubertas, perkembangan janin dan kelahiran, kebutuhan hidup keluarga, sistem reproduksi, untuk anak perempuan; organ reproduksi wanita, menstruasi, sindrom pramenstruasi, untuk anak laki-laki; organ reproduksi laki-laki, dorongan seksual, percabulan dan hukuman perzinaan dan pernikahan, perceraian, kebersihan dan lain-lain.

Lingkungan yang tepat dalam proses pendidikan seks bagi remaja adalah rumah dan sekolah. Penelitian ini difokuskan pada lingkungan sekolah, karena sekolah merupakan tempat bagi individu untuk memperoleh pendidikan berdasarkan aturan-aturan yang telah disepakati bersama. Oleh karena itu pendidikan seksual ini akan menjadi sangat tepat untuk diberikan di sekolah. Sayangnya selama ini belum banyak sekolah yang memiliki program tersebut, oleh karena itu peneliti bertujuan untuk menerapkan model pendidikan seksual ini sebagai upaya untuk meningkatkan pengetahuan dan keterampilan guru dalam memberikan materi pendidikan seks. Penelitian ini juga bertujuan untuk mengetahui 
efektivitas intervensi yang diterapkan dalam meningkatkan pengetahuan, perubahan sikap dan intensi terhadap perilaku seks pranikah.

\section{METODE}

Penelitian ini menggunakan desain penelitian eksperimen one group pretest-posttest design, yaitu menggunakan satu kelompok tanpa ada kelompok perbandingan. Desain ini menggunakan pretest diawal sebagai baseline kemudian diberikan intervensi dan terakhir dilakukan posttest untuk mengetahui perbedaan hasil dari pretest yang telah dilakukan sebelumnya.

Penelitian ini dilakukan di salah satu sekolah yang ada di Malang. Subjek penelitiannya adalah guru dan siswa yang telah dipilih berdasarkan karakteristik tertentu. Ada 6 guru yang terlibat yaitu 3 dari guru Bimbingan dan Konseling dan 3 guru mata pelajaran lain. Peneliti bekerjasama dengan wakil kepala sekolah bagian kurikulum untuk melibatkan guru dalam proses penelitian ini. Siswa yang terlibat adalah 60 siswa yang telah memiliki syarat tertentu yaitu pernah berpacaran atau masih berpacaran. Baik guru maupun siswa telah menyapakati untuk mengikuti kegaiatan dari awal hingga selesai.

Instrumen yang digunakan dalam penelitian ini berbentuk skala. Ada 3 skala yang harus diisi oleh siswa yang mencakup pengetahuan, sikap dan intensi. Sedangkan ada 1 skala yang harus diisi oleh guru yang didalamnya sudah mencakup aspek pengetahuan dan penilaian kemampuan diri terkait dengan keterampilan dalam mengajar Pendidikan seks di kelas.

Penelitian dilakukan dengan 2 tahap, yaitu tahap pertama untuk guru dan tahap kedua untuk siswa. Baik untuk guru maupun untuk siswa prosedurnya sama yaitu diawali dengan pretest, kemudian intervensi dan diakhiri dengan posttest.

Penelitian yang dilakukan terhadap guru diawali dengan pretest untuk mengetahui pengetahuan guru tentang pendidikan seks serta mengetahui skill mereka dalam mengajar Pendidikan seks di kelas. Berikutnya dilakukan proses FGD untuk menggali data lebih lanjut tentang proses Pendidikan seks di sekolah dan harapan-harapan dalam mengikuti kegiatan tersebut. Sedangkan pada siswa, pretest dilakukan untuk mengetahui tingkat pengetahuan, sikap dan intensi siswa terhadap perilaku seks pranikah.

Setelah pretest selesai maka dilanjutkan dengan memberikan intervensi diberikan sebanyak 4 kali pertemuan dengan durasi 90 menit. Rangkaian materi yang diberikan seperti pada tabel 1 . 
Tabel 1.

Materi Pendidikan Seksual untuk Guru

\begin{tabular}{|c|c|c|}
\hline Pertemuan & Aspek & Materi \\
\hline 1. & Kognitif & $\begin{array}{l}\text { - Pengetahuan tentang perkembangan remaja dan } \\
\text { faktor-faktor yang mempengaruhi } \\
\text { - } \quad \text { Karakteristik remaja }\end{array}$ \\
\hline 2. & $\begin{array}{l}\text { Norma dan } \\
\text { Agama }\end{array}$ & $\begin{array}{l}\text { - Norma sosial dan budaya yang berlaku khususunya di } \\
\text { wilayah setemoat subjek } \\
\text { - Kewajiban dan larangan agama terkait dengan usia } \\
\text { baliq }\end{array}$ \\
\hline 3. & Kesehatan & $\begin{array}{l}\text { Kebersihan diri, pencegahan tertularnya penyakit kelamin } \\
\text { dan dampak dari perilaku seks pranikah }\end{array}$ \\
\hline 4. & Kepribadian & Asertifitas, self-efficacy dan self-image \\
\hline
\end{tabular}

Perbedaan intervensi yang diberikan kepada guru dan siswa adalah terletak pada tujuannya. Intervensi yang dilakukan terhadap guru dilakukan untuk meningkatkan pengetahuan dan keterampilan dalam mengajar pendidikan seks, sedangkan pada siswa untuk meningkatkan pengetahuan serta merubah sikap dan menurunkan intensi untuk melakukan seks pra-nikah.

\section{HASIL}

Penelitian ini melibatkan 6 guru dan 60 siswa yang telah bersedia untuk mengikuti kegiatan mulai dari awal hingga akhir penelitian. Peneliti perlu memastikan kesediaan subjek khususnya pada siswa, karena jika mereka tiba-tiba mengundurkan diri akan berdampak pada validitas penelitian. Berikut data subjek penelitian;

Tabel 2.

Demografi Karakteristik Guru

\begin{tabular}{ccc}
\hline \multicolumn{1}{c}{ Karakteristik } & Frekuensi & Persentase \\
\hline Usia & 3 & $50 \%$ \\
32-3 Tahun & 2 & $33,3 \%$ \\
35-36 Tahun & 1 & $16,7 \%$ \\
37-38 Tahun & & \\
Level Pendidikan & 4 & $66,7 \%$ \\
S1 & 2 & $33,3 \%$ \\
S2 & & \\
Mata Pelajaran yang diampu & 3 & $50 \%$ \\
Bimbingan dan Konseling & 1 & $16,7 \%$ \\
Agama & 2 & $33,3 \%$ \\
Biologi & & \\
\hline
\end{tabular}

Total semua guru yang terlibat dalam penelitian ini adalah 6 orang perempuan. Kategori usia mereka berada pada fase dewasa awal dan semua guru telah berstatus menikah. 
Tanggungjawab pelajaran pada guru yang terlibat dalam penelitian ini adalah Bimbingan \& Konseling, Agama dan Biologi.

Tabel 3.

Perbandingan Pengetahuan dan Keterampilan Mengajar Guru

\begin{tabular}{|c|c|c|c|c|c|c|c|}
\hline Intervensi & Mean & $\mathrm{N}$ & Std. deviation & $\mathrm{r}$ & $\mathrm{t}$ & df & Sig. \\
\hline \multirow[t]{2}{*}{ Sebelum } & 4,17 & 6 & 1,47196 & & & & \\
\hline & & & & $-0,878$ & $-20,823$ & 5 & 0,000 \\
\hline Sesudah & 22,33 & 6 & 1,03280 & & & & \\
\hline
\end{tabular}

Hasil analisis yang telah dilakukan menunjukkan bahwa nilai mean sebelum dilakukan intervensi adalah 4, 17 dan setelah pelaksanaan adalah 22,33. Hal ini menunjukkan terjadinya peningkatan pengetahuan dan skill mengajar guru setelah mendapatkan intervensi dengan selisih rata-rata -18,16667. Nilai $r$ sebesar $-0,878$ atau jika dikuadratkan maka diperoleh hasil 0,77 (77\%) dengan signifikansi 0,000 artinya bahwa intervensi memberikan sumbangan yang signifikan dalam meningkatkan pengetahuan dan keterampilan guru. Nilai t sebesar $-27,776$ lebih besar dari t hitung, artinya ada perbedaan pengetahuan dan skill mengajar sebelum dan sesudah intervensi. Hal ini tentu saja telah menjawab pertanyaan dari hipotesis, yaitu terdapat peningkatan pengetahuan dan skill guru setelah mengikuti intervensi.

Tabel 4.

Demografi Karakteristik Siswa

\begin{tabular}{lcl}
\hline \multicolumn{1}{c}{ Karakteristik } & Frekuensi & Persentase \\
\hline Jenis Kelamin & & \\
Laki-laki & 19 & $47,5 \%$ \\
Perempuan & 21 & $52,5 \%$ \\
Usia & & \\
$15-16$ & 17 & $42,5 \%$ \\
$17-18$ & 23 & $57,5 \%$ \\
Kelas & & \\
XI & 15 & $37,5 \%$ \\
XII & 15 & $37,5 \%$ \\
XIII & 10 & $25 \%$ \\
Jumlah & $\mathbf{4 0}$ & $\mathbf{1 0 0 \%}$ \\
\hline
\end{tabular}

Mayoritas subjek penelitian adalah perempuan dengan jumlah 52,5\%, sedangkan kebanyakan mereka berada pada usia $17-18$ th dengan jumlah 57,5\%. Adapun skor siswa sebelum dan sesudah intervensi adalah sebagai berikut ; 
Tabel 5.

Perbandingan Sebelum dan Sesudah Intervensi

\begin{tabular}{|c|c|c|c|c|c|c|c|}
\hline Aspek & Sebelum & Sesudah & $\mathrm{N}$ & Std. Dev & $\mathrm{r}$ & $\mathrm{t}$ & sig \\
\hline Pengetahuan & 5,45 & 16,65 & 60 & 1,7736 . & $-0,070$ & $-48,194$ & 0.000 \\
\hline Sikap & 25,35 & 15,16 & 60 & 5,1437 & 0,466 & 15,335 & 0,000 \\
\hline Intensi & 24,22 & 12,47 & 60 & 7,2944 & 0,605 & 12,477 & 0,000 \\
\hline
\end{tabular}

Hasil analisis menunjukkan bahwa untuk pengetahuan memang terjadi peningkatan mean antara sebelum dan sesudah intervensi pada siswa, namun hasil $r$ pada pengetahuan menunjukkan nilai -0,070 artinya bahwa kontribusi intervensi sangat sedikit dalam proses peningkatan pengetahuan siswa tetang pendidikan seks yaitu 4,9\%. Aspek sikap dan intensi menunjukkan penurunan nilai mean dari sebelum dan sesudah intervensi. Aspek sikap menunjukkan makna bahwa sikap siswa yang semula positif (mendukung) dalam memandang perilaku seks pranikah terjadi perubahan kea rah negatif (tidak mendukung) Hal ini terlihat dari mean sebelum adalah 25,35 dan sesudahnya adalah 15,16. Nilai $r$ pada aspek sikap adalah sebesar 0,466 yang jika dikuadratkan diperoleh nilai sebesar 0,22 (22\%), artinya bahwa intervensi ini berkontribusi dalam merubah sikap siswa terhadap seks pranikah sebesar 22\%. Sedangkan pada aspek intensi juga menunjukkan penurunan mean dari 24,22 menjadi 12, 47 setelah intervensi dilakukan. Nilai $\mathrm{r}$ pada aspek intensi sebesar 0,605 dan $\mathrm{R}^{2}$ sebesar $(37 \%)$ artinya bahwa terjadi penurunan intensi terhadap perilaku seks pranikah setelah intervensi dilakukan, dan intervensi ini memberikan kontribusi sebesar $37 \%$ pada penurunan intensi siswa.

\section{DISKUSI}

Berdasarkan perbandingan hasil atau skor yang diperoleh guru antara sebelum dan sesudah intervensi menunjukkan bahwa kegiatan intervensi yang dilakukan dapat meningkatkan pengetahuan guru tentang pendidikan seks dan juga meningkatkan keterampilan guru dalam mengajarkan pendidikan seks di kelas.

Beberapa guru memang pernah mendengar tentang pendidikan seks, namun diantara mereka belum banyak mengetahui tentang materi secara eksplisist tentang pendidikan seks itu sendiri. Selain tidak memiliki pengetahuan yang cukup untuk mengajarkan pendidikan seks di kelas, mereka juga tidak mengetahui bagaimana cara mengajarkan pendidikan seks yang tepat pada siswa (Maimunah, 2017). Oleh karena itu penelitian ini dapat membantu para guru untuk memahami pendidikan seks sekaligus memiliki keterampilan dalam mengajarkan Pendidikan seks di kelas.

Terjadinya peningkatan skor guru pada sebelum dan sesudah intervensi menunjukkan bahwa kegiatan ini efektif dalam mewujudkan pendidikan seks di sekolah. Memang terjadi perdebatan saat dilakukan FGD awal tentang pentingnya pendidikan seks di sekolah. Beberapa guru menyatakan kekhawatirannya tentang dampak negatif yang muncul setelah pendidikan seks diberikan. Alasan yang dikemukakan adalah kecenderungan remaja yang serba ingin tahu dikhawatirkan justru akan mengantarkan remaja terjerumus dalam seks pranikah. Namun, hasil akhir FGD menunjukkan bahwa 
mereka paham mengapa pendidikan seks perlu diberikan di sekolah. Kekuatan dari program ini termasuk landasan teoretis yang digunakan yang berbasis budaya Indonesia yang masih menganut norma sosial, agama dan budaya relevan dengan pendekatan sistematis yang digunakan untuk pengembangan intervensi (Goldman, 2011).

Proses kegiatan yang dilakukan bukan hanya sekali membuat guru semakin percaya diri dalam menyampaikan materi. Kegiatan yang berulang ini membuat keterampilan guru semakin lebih bagus dalam proses pendidikan seks di kelas. Hal ini sesuai dengan pernyataan dari Tortolero, Markham, Peskin, Shegog, Addy, Escobar-Chaves, dan Baumler (2010) yang mengatakan bahwa praktek pendidikan seks berulang mendorong guru untuk menjadi terampil dan memperkuat kepercayaan mereka dalam memberikan materi pendidikan seks.

Intervensi yang dilakukan pada siswa juga menunjukkan perbedaan skor antara sebelum dan sesudah. Aspek pengetahuan nilai mean yang diperoleh siswa sebesar 5,45 dan sesudahnya adalah 16,65 dengan sognifikansi sebesar 0,000. Kondisi ini menunjukkan bahwa terjadi peningkatan pengetahuan antara sebelum dan sesudah intervensi dilakukan. Namun $\mathrm{R}^{2}$ yang sangat kecil yaitu $4,9 \%$, artinya ada banyak faktor lain yang lebih berkontribusi terhadap peningkatan pengetahuan siswa terkait seks pranikah. Peneliti menyimpulkan bahwa sebenarnya mereka sudah mengetahui informasi yang cukup tentang seks pranikah, jadi intervensi ini hanya sekedar memanggil kembali informasi yang tersimpan di memori mereka. Akan tetapi proses ini sangat berharga dalam membentuk sikap dan intensi yang ada pada remaja.

Beberapa subjek penelitian menunjukkan sikap yang positif terhadap seks pranikah. Ini bukan berarti mereka semua terlibat dalam seks pranikah, akan tetapi beberapa diantara mereka menganggap bahwa seks pranikah adalah hal yang biasa meskipun mereka sebenarnya juga tidak melakukannya. Kondisi ini tentu harus menjadi perhatian, karena sikap yang positif terhadap sesuatu akan membuat individu memiliki intensi untuk melakukan sesuatu. Jadi jika remaja memiliki sikap yang positif terhadap seks pranikah, maka kecenderungan dia akan memiliki intensi untuk melakukannya, hanya saja mungkin belum ada kesempatan. Oleh karena itu harus dilakukan upaya untuk merubah sikap tersebut agar tidak terjadi intensi yang berujung pada perilaku seks pranikah.

Hasil analisis penelitian menunjukkan bahwa mean pada aspek sikap sebelum dilakukan intervensi diperoleh hasil sebesar 25,35 dan sesudahnya adalah sebesar 15,17. Artinya terdapat penurunan antara sebelum dan sesudah perlakuan, sehingga dapat dijelaskan bahwa yang semula sikap subjek terhadap seks pranikah adalah positif berubah menjadi negatif setelah intervensi diberikan.

Berlaku pola yang sama pada aspek intensi, nilai mean sebelum intervensi sebesar 24,22 dan sesudahnya adalah 12,47. Hal ini menunjukkan bahwa terjadi penurunan pada aspek intensi, artinya sebelum intervensi dilakukan intensi untuk melakukan seks pranikah adalah tinggi. Bisa jadi hal ini karena sikap positif yang dimiliki subjek terhadap seks pranikah. Namun, setelah mendapatkan intervensi terjadi penurunan intensi, dan hal ini juga sejalan dengan menurunnya skor sikap.

Teori perilaku yang direncanakan atau dikenal dengan theory planned behavior yang dikemukakan oleh dirasa mampu menjelaskan kondisi ini. Ajzen (1991) menyatakan bahwa setiap perilaku yang terjadi pada individu dikarenakan adanya intensi terlebih 
dahulu. Sedangkan intensi disinyalir karena adanya 3 hal yaitu sikap terhadap perilaku, norma subjektif dan persepsi atas control perilaku. Gambaran subjek penelitian yaitu siswa menunjukkan bahwa sebelum intervensi dilakukan mereka memiliki pengetahuan yang kurang tentang seks pranikah, sikap yang yang positif dan intensi yang relative tinggi untuk melakukan seks pranikah. Setelah inervensi dilakukan terjadilah peningkatan pengetahuan yang diiringi dengan sikap yang negative terhadap seks pranikah dan kecenderungan yang menurun terkait intensi seks pranikah. Artinya bahwa ketika individu memiliki informasi yang memadai tentang perilaku seks pranikah akan mengantarkan ia untuk memiliki sikap yang sesuai yaitu memandang bahwa seks pranikah adalah sesuatu yang kurang tepat dan tidak diterima secara sosial. Hal ini juga berdampak pada intensi yang rendah untuk melakukan seks pranikah. Jika intensinya rendah bisa diprediksikan bahwa kecenderungan perilaku seks pranikah yang akan muncul juga rendah.

\section{SIMPULAN DAN IMPLIKASI}

Secara keseluruhan, hasil penelitian menunjukkan bahwa program yang dilakukan dalam bentuk intervensi mampu meningkatkan pengetahuan dan keterampilan guru dalam mengajar materi pendidikan seks di kelas. Sedangkan pada siswa juga dapat meningkatkan pengetahuan tentang seks pranikah, bersikap negatif atau tidak mendukung seks pranikah, serta mengurangi intensi dalam seks pranikah pada remaja. Oleh karena itu, program ini dirasa efektif dalam membantu terwujudnya pendidikan seks di sekolah. Pendidikan seks yang memadai di sekolah dapat mengahalangi keterbatasan komunikasi seksual antara guru dan siswa, sehingga siswa mendapatkan informasi yang tepat dari sumber yang dapat dipercaya. Kondisi ini tentu akan membantu remaja terhindar dari perilaku seks pranikah.

Penelitian ini bermanfaat dalam mencegah terjadinya seks pranikah pada remaja, sehingga dapat dilanjutkan dengan program yang lebih luas di sekolah setempat maupun sekolah-sekolah yang lain. Kerjasama semua pihak sekolah sangat diperlukan agar pendidikan seks di sekolah dapat berlangsung, sehingga guru lebih terlatih dalam mengajar pendidikan seks dan siswa terhindar dari perilaku seks pranikah.

\section{REFERENSI}

Ahmed, S., Abu-Ras, W. \& Arfken, C.L. (2014). Prevalence of risk behaviors among US moslem college student. Journal of Moslem Mental Helath, 8(1).

Ajzen, I. (1991). The theory of planned behavior. Organizational behavior and human decision process, 50, $179-211$

Anderson, L.W., \& Krathwohl, D.R. (2001). A Taxonomy for learning, teaching and assessing: a revision of bloom's taxonomy. New York. Longman Publishing.

Chaves, S.L.E., Tortolero, S.R., Markham, C.M., Low, B.J., Eitel, P., and Thickstun, P. (2005). Impact of the media on adolescent sexual attitude and behaviors. Journal of The American Academy of Pediatrics, 116, DOI:10.1542/peds.2005-0355D 
Goldman, J. D. (2011). An exploration in health education of an integrated theo- retical basis for sexuality education pedagogies for young people. Health Education Research, 26(3), 526e541.

Islam, M.S., \& Rahman, M.M. (2008). Sex education: An islamic view, the Dhaka University Journal of Islamic Studies, Department of Islamic Studies, University of Dhaka, 2(1), January-June

Jaccard, J., Blanton, H., and Dodge T. (2005). Peer influences on risk behavior: an analysis of the effects of a close friend. Journal of Developmental Psychology, 41(1), DOI: 10.1037/0012-1649.41.1.135

Kretsch, N., Mendle, J., Cance, J., D., and Harden, K., P. (2015). Peer group similarity in perceptions of pubertal timing. Journal of Youth Adolescence, DOI $10.1007 /$ s10964-015-0275-3

Kirby, D., Laris, B.A., and Rolleri,L. (2005). Impact of sex and HIV education programs on sexual behaviors of youth in developing and developed countries. Family Health International, Youth Net Program, USA

Notoatmodjo, S. (2007). Promosi Kesehatan dan Ilmu Perilaku. Cetakan I. Jakarta : PT. Rineka Cipta

Pryor, S. (2012). Guidline for the sexual health education component of comprehensive health education. State of Connecticut Department of Education, Middletown

Simon, R.L., Chao, W., Conger, R.D., \& Elder, G.H. (2001). Quality of parenting as mediator of the effect of childhood defiance on adolescent friendship choice and deliquency: A Growth Curve Analysis. Journal of Marriage and Family, 63(1).

Smida, M.A.B., Hadhri, N., Bolje, A., Cafsi, M.E., \& Bedoui, F. (2014). Reproductive cycle and size at first sexual maturity of common pandora pagellus erythrinus (sparidae) from the bay of monastir (Tunisia, Central Mediterranean). Journal of ANNALES. Ser. hist. nat. 24(1).

Terzian, M.A., Andrews, K.M., \& Moore., K.A. (2011). Preventing multiple risky behaviors among adolescent : Seven Srategies. Journal of Research to Result, 24

Tortolero, S. R., Markham, C. M., Peskin, M. F., Shegog, R., Addy, R. C., EscobarChaves, S. L., \& Baumler, E. R. (2010). It's Your Game: Keep It Real: delaying sexual behavior with an effective middle school program. Journal of Adolescent Health, 46(2), 169-179. 